\title{
A Disposable Polymer Lab-On-A-Slide For Point-Of-Care Diagnostics Of Methicillin- Resistant Staphylococcus Aureus (Mrsa)
}

Bu, Minqiang ; R. Perch-Nielsen, Ivan; Skov, Julia ; Sørensen, Karen Skotte; Yi, Sun; E. Pedersen, Michael ; Hansen, Mikkel Fougt; W. Harlow, Kenneth ; Wolff, Anders

\section{Published in:}

Proceedings of the the 17th International Conference on Solid-State Sensors, Actuators and Microsystems

Link to article, DOI:

10.1109/Transducers.2013.6627214

Publication date:

2013

Document Version

Early version, also known as pre-print

Link back to DTU Orbit

Citation $(A P A)$ :

Bu, M., R. Perch-Nielsen, I., Skov, J., Sørensen, K. S., Yi, S., E. Pedersen, M., Hansen, M. F., W. Harlow, K., \& Wolff, A. (2013). A Disposable Polymer Lab-On-A-Slide For Point-Of-Care Diagnostics Of Methicillin-Resistant Staphylococcus Aureus (Mrsa). In Proceedings of the the 17th International Conference on Solid-State Sensors, Actuators and Microsystems IEEE. https://doi.org/10.1109/Transducers.2013.6627214

\section{General rights}

Copyright and moral rights for the publications made accessible in the public portal are retained by the authors and/or other copyright owners and it is a condition of accessing publications that users recognise and abide by the legal requirements associated with these rights.

- Users may download and print one copy of any publication from the public portal for the purpose of private study or research.

- You may not further distribute the material or use it for any profit-making activity or commercial gain

- You may freely distribute the URL identifying the publication in the public portal 


\title{
A DISPOSABLE POLYMER LAB-ON-A-SLIDE FOR POINT-OF-CARE DIAGNOSTICS OF METHICILLIN-RESISTANT STAPHYLOCOCCUS AUREUS (MRSA)
}

\author{
Minqiang Bu ${ }^{1}$, Ivan R. Perch-Nielsen ${ }^{1}$, Julia Skov ${ }^{1}$, Karen S. Sørensen ${ }^{1,2}$, Yi Sun $^{2}$, \\ Michael E. Pedersen ${ }^{1}$, Mikkel F. Hansen ${ }^{2}$, Kenneth W. Harlow ${ }^{1}$ and Anders Wolff ${ }^{2, *}$ \\ ${ }^{1}$ Center for integrated Point of Care Technologies (CiPoC), DELTA, Venlighedsvej 4, DK-2970, \\ Hørsholm, Denmark \\ ${ }^{2}$ DTU Nanotech, Technical University of Denmark, DK-2800, Kgs. Lyngby, Denmark
}

\begin{abstract}
This paper reports the design, fabrication and experimental verification of a polymer microfluidic labon-a-slide for rapid detection of methicillin-resistant Staphylococcus aureus (MRSA). MRSA cells were captured in a lysis chamber using magnetic beads, followed by thermal lysis. The released DNA was transferred into a second chamber for polymerase chain reaction (PCR) amplification. Fluidic control in the device was accomplished by pneumatic actuation of a micropump and five microvalves integrated on the device. The mecA gene from MRSA was successfully amplified by real-time PCR within $35 \mathrm{~min}$. Presence of the correct PCR amplicon (186 bp) was verified using capillary electrophoresis. The results demonstrate the utility of a low-cost disposable polymer microfluidic system for rapid pathogen detection for point-of-care diagnostics.
\end{abstract}

\section{KEYWORDS}

Microfluidics, MRSA detection, lab-on-a-slide, pointof-care diagnostics, cell lysis, PCR amplification.

\section{INTRODUCTION}

The rapid development of microfluidic technologies has enabled advances of point-of-care (POC) diagnostics in many applications [1-3]. Examples include point-ofcare immunodiagnostics [4] and diagnostics for infectious disease [5-7]. Nucleic acid based testing, is among the fastest growing technology for biomedical diagnostics in recent years. PCR amplification of DNA samples in microfluidic based lab-on-a-chip format [8-10] has existed for two decades and together with rapid developments in microtechnology, has fostered increasing commercial development of PCR based testing.

Detection of MRSA has been carried out widely in microfluidic systems, for example, by coupling PCR and microarray hybridization in a disposable plastic microfluidic flow cell [11], by multiplexed PCR on a digital microfluidic platform [12], by ethidium monoazide pre-treatment and PCR of a DNA sample from live MRSA cells in a PDMS-glass based microfluidic system [13], by loop-mediated isothermal amplification (LAMP) [14], or by using a genotyping assay by real-time PCR on a centrifugal microfluidic platform [15].

In this work, we combine polymer fabrication technologies (injection moulding, laser ablation, ultrasonic welding and lamination) to manufacture a disposable polymer lab-on-a-slide. Re-usable external pneumatic actuators [16] were used to actuate an chipintegrated thin elastomeric film that forms the basis of a micropump and microvalves for fluidic control. Re-usable external silicon heaters with integrated temperature sensors were employed to heat the cell lysis chamber and PCR chamber [17]. The functionality of the lab-on-a-slide was verified by on-chip thermal lysis of MRSA cells and PCR amplification of the mecA gene from MRSA.

\section{DEVICE DESIGN}

Fig. 1a shows an exploded view of the construction of the polymer lab-on-a-slide with a footprint similar to that of a microscope slide $\left(26 \times 76 \mathrm{~mm}^{2}\right)$. It contains six components: a TOPAS ${ }^{\circledR}$ Luer connector, a TOPAS ${ }^{\circledR}$ slide as the main body, a PCR tape as cover layer, a polyurethane film, a TOPAS $^{\circledR}$ bottom plate, and a thin TOPAS $^{\circledR}$ cover. Fig. 1b illustrates the main functional components of the lab-on-a-slide. There are two main reaction chambers on the slide: a thermal lysis chamber (1) and a PCR amplification chamber (2). These two chambers have a volume of $15 \mu \mathrm{L}$ and $8 \mu \mathrm{L}$, respectively. Five microvalves (3) and one micropump (4) are used to control the liquid flow in the lab-on-a-slide. Luer connectors are used as liquid reservoirs for the sample (5), the PCR mixture (6) and the PCR amplicon (7). Vacuum $(-0.015$ bar) is applied on the waste exit (8) to draw the sample into the lysis chamber which is positioned over a retractable permanent magnet array, and to evaporate the liquid in the original sample.
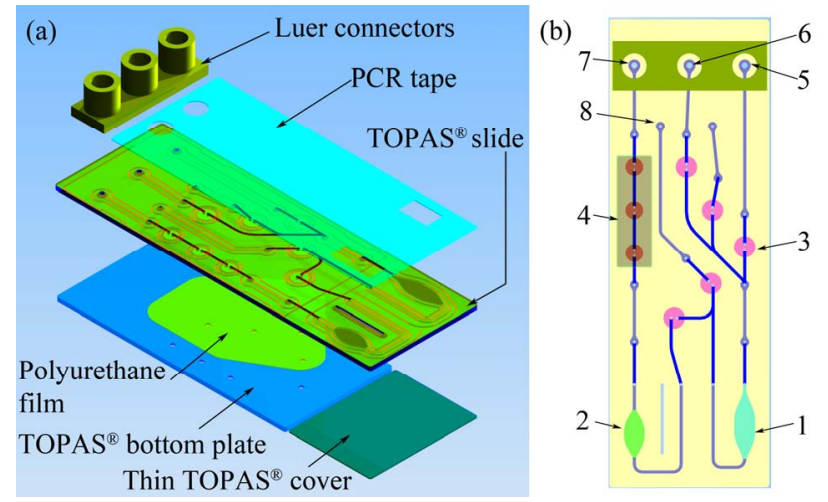

Figure 1: An exploded illustration (a) and a top view (b) of the design of the lab-on-a-slide.

The cross-sectional views shown in Fig. 2 illustrate the details of the design of the micropump and microvalve. The polyurethane film $(50 \mu \mathrm{m}$ thick $)$ is clamped between the TOPAS ${ }^{\circledR}$ slide and TOPAS ${ }^{\circledR}$ bottom plate during ultrasonic welding of these two components. The polyurethane film is used as actuation membrane in the pump and valve chambers when a pressure or vacuum 
is supplied via the through holes on the TOPAS ${ }^{\circledR}$ bottom plate after the lab-on-a-slide is mounted on a platform [16] for testing. As shown in Fig. 2a, three pump chambers are connected in series and form a peristaltic micropump. The pump chambers and valve chambers are $2.5 \mathrm{~mm}$ and $3 \mathrm{~mm}$ in diameter, respectively. Fig. $2 \mathrm{~b}$ and $2 \mathrm{c}$ are illustrations of opening and closing of the pump/valve chambers, respectively. When a vacuum is supplied, the polyurethane film is pulled down and the pump/valve chamber opens. When an overpressure from compressed air is supplied, the membrane is pushed against the two through-holes on the top of the pump/valve chamber and the pump/valve chamber is closed. In the system, a vacuum of -0.8 bar and a pressure of 3.5 bar are used for the pneumatic actuation of the micropump and microvalves.

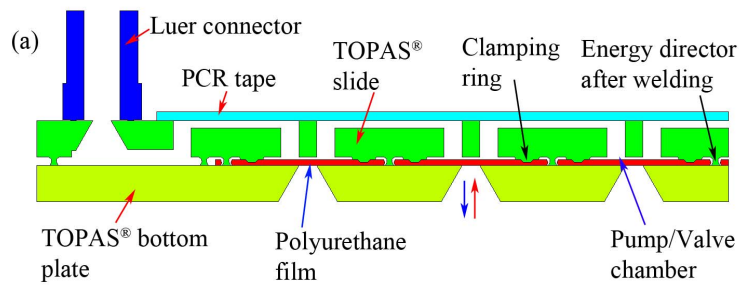

(b)

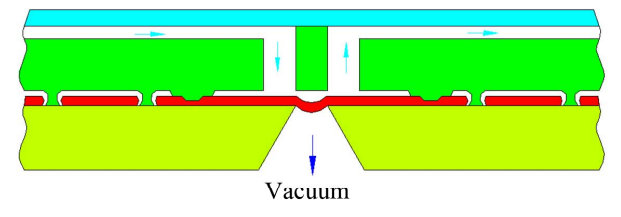

(c)

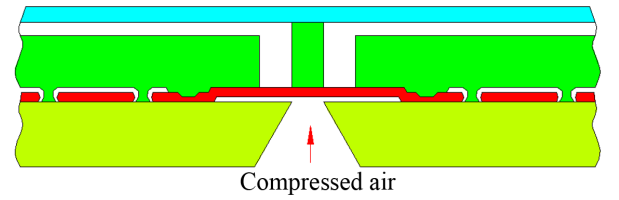

Figure 2: Cross-sectional view (a) of the design of the micropump and microvalve. Panels (b) and (c) illustrate the opening and closing of the pump/valve chamber, respectively. The figure is not drawn to scale.

\section{DEVICE FABRICATION}

The disposable polymer lab-on-a-slide was fabricated with a process as illustrated in Fig. 3. The fabrication process started with the milling of three aluminium inserts for injection moulding of the TOPAS ${ }^{\circledR}$ slide (1), the Luer connectors (2) and the TOPAS $^{\circledR}$ bottom plate (3). TOPAS $^{\circledR}$ 5013L-10 was used for injection moulding of the three above mentioned components (Fig. 3a). A $\mathrm{CO}_{2}$ laser was used to cut the PCR tape (4) and polyurethane film (5) (Fig. 3b). Due to limitations of the available injection moulding tool, structures can only be injection moulded on the bottom side of the TOPAS ${ }^{\circledR}$ slide. Thus, a micro milling machine was used to mill connection channels (200 $\mu \mathrm{m}$ deep and $500 \mu \mathrm{m}$ wide) and small through holes $(500 \mu \mathrm{m}$ in diameter $)$ in the micropump/valve chambers from the top of the TOPAS ${ }^{\circledR}$ slide (Fig. 3c). The thin TOPAS ${ }^{\circledR}$ cover (6) for covering the PCR chamber and cell lysis chamber was also milled from $250 \mu \mathrm{m}$ thick TOPAS ${ }^{\circledR} 5013 \mathrm{~L}-10$ sheets.

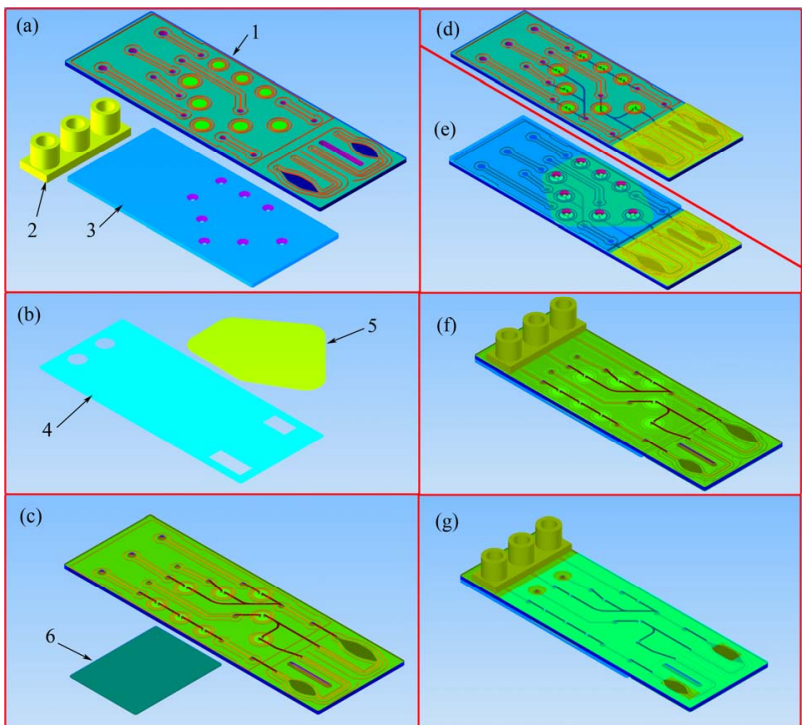

Figure 3: Illustration of the fabrication process of the labon-a-slide.

After all six components were machined, they were bonded together. First, the thin TOPAS $^{\circledR}$ cover was bonded onto the bottom side of the TOPAS ${ }^{\circledR}$ slide using ultrasonic welding to cover the PCR chamber and cell lysis chamber (Fig. 3d). Then, the TOPAS ${ }^{\circledR}$ bottom plate was bonded onto the bottom side of the TOPAS ${ }^{\circledR}$ slide using ultrasonic welding, while the polyurethane film was clamped between the two TOPAS ${ }^{\circledR}$ parts (Fig. 3e). After ultrasonic welding, the $50 \mu \mathrm{m}$ thick polyurethane film is deformed by $10-20 \mu \mathrm{m}$ and a sealing in the pump/valve chambers was achieved. In the last bonding step, the TOPAS $^{\circledR}$ Luer connectors were bonded onto the top side of the TOPAS ${ }^{\circledR}$ slide using ultrasonic welding (Fig. 3f). The fabrication process ended with manual lamination of PCR tape to cover all connection channels on the top side of the TOPAS ${ }^{\circledR}$ slide (Fig. $3 \mathrm{~g}$ ). Fig. 4 shows an image of the lab-on-a-slide after assembly.

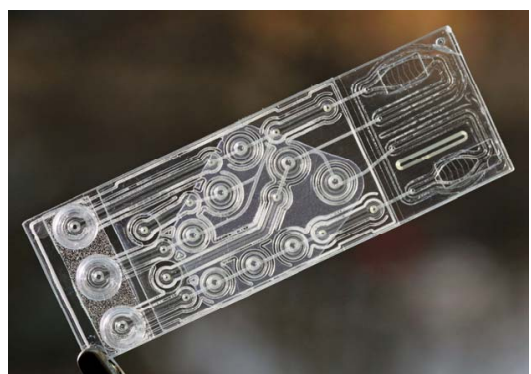

Figure 4: Image of an assembled TOPAS $S^{(R)}$ lab-on-a-slide with a dimension of $26 \times 76 \mathrm{~mm}^{2}$.

\section{EXPERIMENTAL PROCEDUCE}

Prior to the on-slide experimental process, MRSA strain USA300 cells eluted from a Copan flocked swab were captured using DynaBeads ${ }^{\circledR}$ MyOneTM tosyl activated magnetic beads, coupled with an antibody raised against UV inactivated whole $S$. aureus cells. Then the process for MRSA detection in the lab-on-a-slide followed the sequence illustrated in Fig. 5 (a-f). (a): Microvalves V3 and V4 were initially open, while valves V1, V2 and V5 and all three pump chambers were closed. A $50 \mu \mathrm{L}$ sample containing the bead-bound cells was 
loaded into the sample reservoir using pipette. By applying a vacuum of -0.015 bar at the waste exit, the cells on magnetic beads were drawn and captured in the lysis chamber, under the magnetic force from the $\mathrm{NdFeB}$ magnets array located beneath the lysis chamber. (b): After all magnetic beads were captured, the liquid contained in the sample was removed by vacuum drying using a vacuum of -0.345 bar for $1 \mathrm{~min}$. (c): With the valves V1 and V5 open and valves V2, V3 and V4 closed, $35 \mu \mathrm{L}$ of the PCR master mix solution was pipetted into the PCR mixture reservoir and drawn into the lysis chamber using the micropump. The flow was stopped when the front meniscus of the liquid reached valve V5. (d): When all valves were closed, thermal lysis of MRSA cells was carried out at $92{ }^{\circ} \mathrm{C}$ for $1 \mathrm{~min}$. (e): After thermal lysis, valves V1 and V5 were opened. The released DNAPCR master mix solution was pumped into the PCR chamber by the on-chip micropump while beads were retained in the lysis chamber. The flow was stopped when the front meniscus of the liquid reached the middle pump chamber. In this way, the PCR chamber was filled with the DNA-PCR master mix suspension. (f): After closing all valves and pump chambers, real-time PCR amplification of mecA gene from MRSA was carried out. The PCR amplicon was pumped back into the PCR mixture reservoir and was collected for further analysis.

(a)

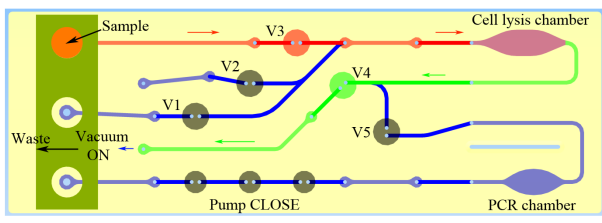

(b)

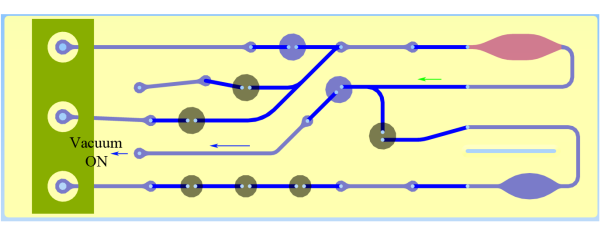

(c)

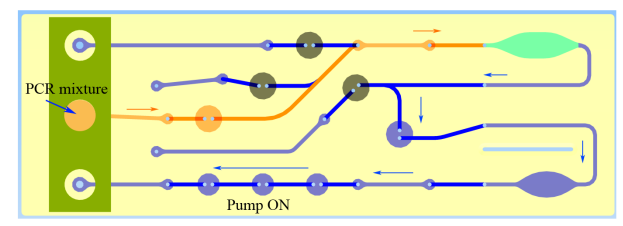

(d)

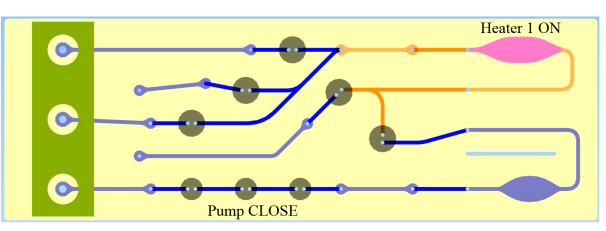

(e)

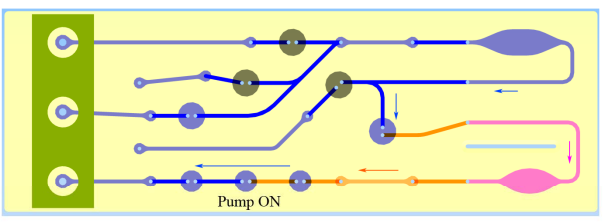

(f)

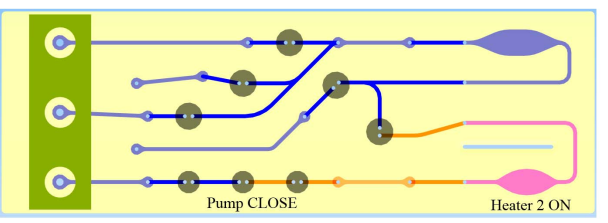

Figure 5: Experimental procedure of MRSA detection.

\section{RESULTS AND DISCUSSION}

The functionality of the system was verified by detection of MRSA USA300 bacterial cells using the experimental procedures described above. Fig. 6 shows a portion of the programmed temperature cycling protocol for the MRSA assay. During PCR amplification an optimized overshooting and undershooting temperature control method [17] was applied to achieve rapid temperature ramping in the PCR chamber. The dashed line shown in Fig. 7 is the temperature setting of the silicon heater. The solid line is the temperature of the silicon heater measured by the integrated $\mathrm{Pt}$ resistive temperature sensor. Since the PCR chamber in the TOPAS $^{\circledR}$ slide is only heated by the silicon heater from one side, there is a temperature gradient between the temperature measured at the heater surface and the PCR chamber. Therefore, for the DNA denaturation, primer annealing and extension steps, the temperature of the silicon heater was set at $95.5{ }^{\circ} \mathrm{C}, 56{ }^{\circ} \mathrm{C}$ and $73{ }^{\circ} \mathrm{C}$, respectively to compensate for the temperature gradient. This setting leads to an approximate chamber temperature of $94{ }^{\circ} \mathrm{C}, 55^{\circ} \mathrm{C}$ and $72{ }^{\circ} \mathrm{C}$, respectively. With this overshooting/undershooting method, rapid heating and cooling rates of about $4.3{ }^{\circ} \mathrm{C} / \mathrm{s}$ and $5^{\circ} \mathrm{C} / \mathrm{s}$, respectively, were achieved in the PCR chamber [17]. One complete cycle had a duration of approximately $1 \mathrm{~min}$, including the time for temperature ramping from one step to the next. The complete on-slide assay time from cell lysis to completion of 36 cycles of PCR amplification required approximately $40 \mathrm{~min}$.

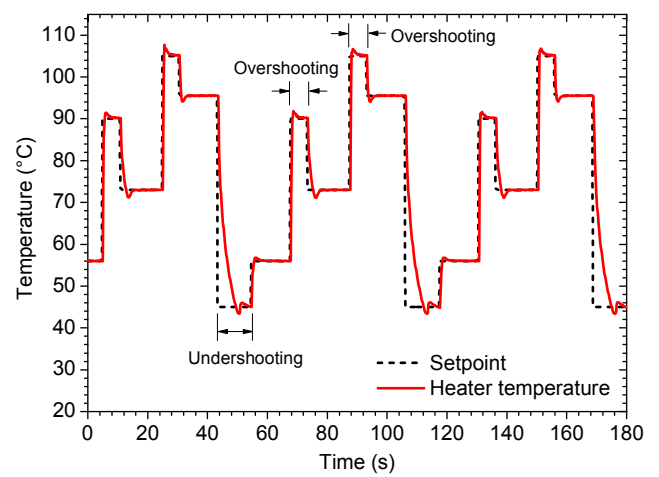

Figure 6: Temperature profile of the PCR thermal cycling, with an optimized overshooting and undershooting temperature control method for rapid ramping of temperature in the PCR chamber.

Fig. 7 shows the on-slide real-time fluorescence signal during PCR amplification of the mecA gene from two MRSA samples and one negative control not containing MRSA cells. EvaGreen ${ }^{\circledR}$ DNA intercalating dye was employed for real-time fluorescence measurements. For positive sample 1, 36 cycles were run, while 51 cycles were run for sample 2 . A possible reason for the obvious difference in the real-time signals from samples 1 and 2 is due to the different initial DNA concentrations in the PCR chamber. This could happen during the complicated process of capturing of MRSA cells, thermal lysis and then releasing of DNA with different efficiency, or during the transportation of the DNA from cell lysis chamber into the PCR chamber. A negative control sample without MRSA cells was also 
processed in the lab-on-slide with the same procedures as positive samples 1 and 2 and 36 cycles were run in total.

The specific amplification of the targeted gene (186 bp) from positive samples 1 and 2, and the negative control without MRSA cells was verified by capillary electrophoresis analysis using Agilent Bioanalyzer. Fig. 8 shows a graph from Bioanalyzer analysis of three on-chip PCR amplicons. It reveals the successful PCR amplification of specific mecA gene of MRSA contained in the positive samples 1 and 2 . In the negative control sample without MRSA cell, only primer dimers are found in the Bioanalyzer graph (lane 3). This also verifies the successful lysis of MRSA cell in the cell lysis chamber. The specific amplification of mecA gene of MRSA has also been achieved on a commercial thermocycler by using the same protocol as on-chip amplification.

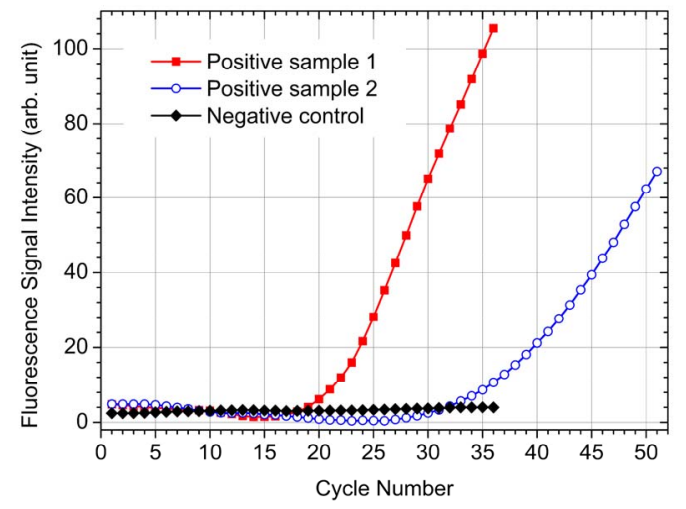

Figure 7: Fluorescence signal of real-time PCR of three samples: positive samples 1 and 2, and negative control without DNA template (without MRSA cells in the original sample).

[bp]

[bp]

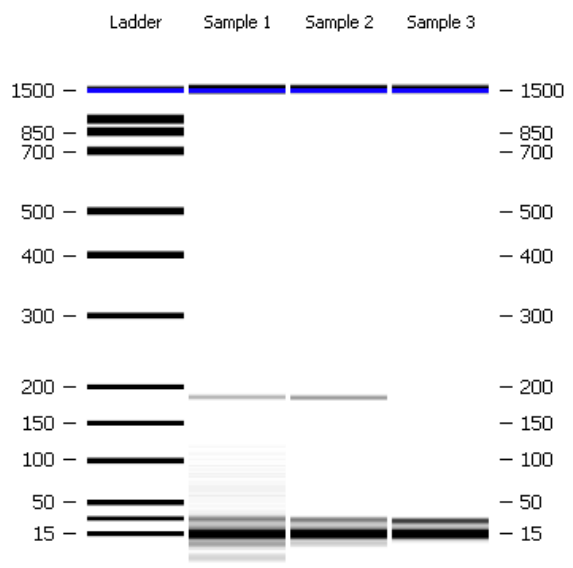

Figure 8: A Bioanalyzer graph of an analysis of three PCR on-slide reactions revealing the successful amplification of specific mecA amplicon from MRSA. From left to right, lane L: molecular weight ladder; lane 1\&2: PCR amplicons from positive sample 1 with 36 thermal cycles and from positive sample 2 with 51 thermal cycles, respectively; lane 3: PCR amplicon from negative control with 36 thermal cycles. The sizes of the PCR amplicons for samples 1 and 2 are all $186 \mathrm{bp}$.

\section{CONCLUSION}

We have successfully developed a disposable polymer lab-on-a-slide capable of rapid detection of MRSA bacterial cells from capture cells on magnetic beads to real time PCR amplification of its $m e c A$ gene within $40 \mathrm{~min}$. This demonstrates the functionality of the system for rapid pathogen detection, e.g., for point-of-care diagnostics applications. The low-cost polymer fabrication technologies, e.g. injection moulding, laser ablation, ultrasonic welding and lamination have been employed to fabricate the lab-on-a-slide and this ensures its great potential for commercialization.

\section{ACKNOWLEDGEMENTS}

The authors would like to acknowledge the financial support from Center for integrated Point of Care technologies (CiPoC) funded by the Danish Council for Technology and Innovation, and the LABONFOIL Project of the $7^{\text {th }}$ Framework Program (FP7) of the European Commission (Project number: 224306).

\section{REFERENCES}

[1] V. Gubala, L. F. Harris, A. J. Ricco, et al., Anal. Chem., vol. 84, pp. 487-515, Jan 172012.

[2] J. M. Ruano-Lopez, M. Agirregabiria, G. Olabarria, et al., Lab Chip, vol. 9, pp. 1495-1499, 2009.

[3] S. Choi, M. Goryll, L. Y. M. Sin, et al., Microfluid. Nanofluid., vol. 10, pp. 231-247, Feb 2011.

[4] L. Gervais, N. de Rooij, and E. Delamarche, Adv. Mater., vol. 23, pp. H151-H176, Jun 242011.

[5] S. Park, Y. Zhang, S. Lin, et al., Biotechnol. Adv., vol. 29, pp. 830-839, Nov-Dec 2011.

[6] C. D. Chin, T. Laksanasopin, Y. K. Cheung, et al., Nat. Med., vol. 17, pp. 1015-1019, Aug 2011.

[7] A. M. Foudeh, T. F. Didar, T. Veres, et al., Lab Chip, vol. 12, pp. 3249-3266, 20122012.

[8] Y. Zhang and P. Ozdemir, Anal. Chim. Acta., vol. 638, pp. 115-125, Apr 132009.

[9] P. A. Auroux, Y. Koc, A. deMello, et al., Lab Chip, vol. 4, pp. 534-546, 2004.

[10] M. Bu, T. Melvin, G. J. Ensell, et al., J. Micromech. Microeng., vol. 13, pp. S125-S130, 2003.

[11] C. G. Cooney, D. Sipes, N. Thakore, et al., Biomed. Microdevices, vol. 14, pp. 45-53, 2012.

[12] Z. Hua, J. L. Rouse, A. E. Eckhardt, et al., Anal. Chem., vol. 82, pp. 2310-2316, 2010.

[13] Y.-H. Liu, C.-H. Wang, J.-J. Wu, et al., Biomicrofluidics, vol. 6, p. 034119, 2012.

[14] C.-H. Wang, K.-Y. Lien, J.-J. Wu, et al., Lab Chip, vol. 11, pp. 1521-1531, 2011.

[15] M. Focke, F. Stumpf, B. Faltin, et al., Lab Chip, vol. 10, pp. 2519-2526, 2010.

[16] M. Bu, I. R. Perch-Nielsen, Y. Sun, et al., in Digest of Technical Papers: Transducers 2011, Beijing, China, 2011, pp. 1244-1247.

[17] M. Bu, I. R. Perch-Nielsen, K. S. Sørensen, et al., in Proc. MME2012, Ilmenau, Germany, 2012, p. C17.

\section{CONTACT}

*A. Wolff, tel: +45-45256305; awol@nanotech.dtu.dk 